\title{
Profile of geographical variation in marginal land and its relationship with the fruit tree species richness in Jombang District, Indonesia
}

\author{
ZULFIKAR $^{1,2, \boldsymbol{v}}$, ENDANG ARISOESILANINGSIH ${ }^{3}$, SERAFINAH INDRIYANI $^{3}$, \\ ADJI ACHMAD RINALDO FERNANDES ${ }^{4}$ \\ ${ }^{1}$ Department of Informatical Science, Faculty of Informatical Technology, Universitas KH. A. Wahab Hasbullah. J1. Garuda 9, Tambakberas, Jombang \\ 61419, East Java, Indonesia. Tel. /fax.: +62-321-853533, `email: zulfikardia@gmail.com \\ ${ }^{2}$ Program of Biology, Department of Biology, Faculty of Mathematics and Natural Sciences, Universitas Brawijaya. Jl. MT Haryono 169, Malang 65145, \\ East Java, Indonesia \\ ${ }^{3}$ Departmen of Biology, Faculty of Mathematics and Natural Sciences, Universitas Brawijaya. Jl. MT Haryono 169, Malang 65145, East Java, Indonesia \\ ${ }^{4}$ Departmen of Statistical, Faculty of Mathematics and Natural Sciences, Universitas Brawijaya. Jl. MT Haryono 169, Malang 65145, East Java, \\ Indonesia
}

Manuscript received: 16 March 2021. Revision accepted: 24 May 2021.

\begin{abstract}
Zulfikar, Arisoesilaningsih E, Indriyani S, Fernandes AAR. 2021. Profile of geographical variation in marginal land and its relationship with the fruit tree species richness in Jombang District, Indonesia. Biodiversitas 22: 3315-3325. The purpose of this study was to determine the sites of fruit tree species richness, in order to analyze the relationship between the locations with fruit tree diversity, and geographical variations, towards the success of marginal land conservation in Jombang Regency. The study area covered four districts, and was divided into 11 sites with different slopes and altitudes. Multivariate analysis was carried out using the $\mathrm{R}$ program. The results showed that the structure and composition of fruit trees were discovered to be 21 species from 14 families. The uniqueness of the fruit trees was shown in Tamarindus indica and Cocos nucifera, which were observed as rare plants on slopes with high and low altitudes, respectively. The results of the geographical variation analysis also showed that the slope and elevation with values of 0.5889 and 0.5077 , respectively, were significantly correlated with the site of fruit plant species richness at the $(\alpha) 0.05$ level, as the response formed was not linear for the three geographical diversities studied. Also, the model built between site, slope, and elevation towards the fruit tree species richness was acceptable, due to the fact that the value $(\operatorname{Pr}>\mathrm{F})=0.004$ was very significant at the ( $\alpha$ ) 0.001 level.
\end{abstract}

Keywords: ANOVA, geographical variation, fruit trees, species richness, NMDS, marginal land

Abbreviations: ANOVA; Analysis of Variance, NMDS; Non-metrics Multidimensional Scaling, DCA; Detrended Correspondence Analysis, CA; Correspondence Analysis, CCA; Canonical Correspondence Analysis, CDA; Cluster Dendrogram Analysis.

\section{INTRODUCTION}

The conservation success is inseparable from environmental conditions and geographical variations in one ecological entity. Spatial and geographical variations in species richness have been a well-documented pattern in ecology (Rosenzweig 1995). Species richness is the total number of different breeds, while equity is the abundance distribution (for example number of individuals, biomass, and others.) in each group (Ludwig and Reynolds 1988). Also, environmental factors such as abiotic constraints, biotic interactions, disturbances, and historical processes, have been designed as the main drivers producing this variability (Ricklefs et al. 2004). Specifically, slope and elevation have been considered to be one of the most important drivers of geographical variability in plant species richness (Allen et al. 2002). Recently, the study linking climate to biodiversity has received major attention for predicting the possible effects of climate warming (Gedan and Bertness 2009), especially leading to marginal land status. Zhang et al. (2010), also stated that the community composition in ecological units was generally sensitive to local environmental conditions, such as soil chemistry, topography, sunlight, and atmospheric humidity.

The latitude and elevation patterns of plant species richness are often associated with different climatic variables, such as rainfall, temperature, and evapotranspiration. Several significant relationships between plant species richness, latitude, and altitude (O'Brien et al. 2000; Whittaker and Field 2000; Kluge et al. 2006) have been observed, with the climate gradients associated with these geographical trends proposed as an explanation. Also, the latitudinal variation of breed diversity, where species richness tends to increase near the equator and decreases toward the poles, has been widely recognized by biologists (Peet 1978; Wang et al. 2006). Moreover, longitudinal variations in species richness have been documented for birds (Jetz and Rahbek 2001) and vascular plants (Qian 1999). Generally, species richness increases with rainfall and temperature, although it decreases in wet and cold or warm and dry climates (Ferrer-Castán and Vetaas 2005). Several studies have also documented a unimodal relationship between species richness and productivity, as measured by evapotranspiration (Field et al. 2005). 
The establishment of conservation areas on marginal lands, which focuses on biodiversity conservation and environmental conservation, allows for multiple levels of multi-use resource management. These conservation areas have become an important component of most regional strategies, in order to reduce the risk of environmental damage from erosion, which is often cited from contemporary biodiversity resources. This condition requires efforts to overcome conservation resources, due to confusion between important factors in maintenance design, namely scale and errors in data collection (Flather et al. 2009). The problem is that there is no clear information on the relationship between geographical variation and fruit tree species richness, as this issue is often related to the impact of human activities. The impact of human activities on plant diversity is projected to have broad global consequences (Sala et al. 2000), with the extent of these effects not even (Cincotta et al. 2000; Imhoff et al. 2004; Evans et al. 2006). Furthermore, the uneven spatial distribution of plant diversity is one of the most striking patterns in macroecology (Gaston 2000; Myers et al. 2000). However, there is a dual pattern of biodiversity and human impact area regional concentrations. These concentrations which are often spatially correlated (Gaston 2006), have promoted the development of geographical approaches to conservation, and raised the underlying hope that most species diversity are conserved in a relatively small fraction of the landscape (Reid 1998). The information on the relationship between geographical variation and species richness is also needed, in order to design conservation in marginal land.

Geographical perspectives have also been triggered by the rapidly growing availability of spatially explicit data on species occurrence and abundance (Gaston et al. 1998). The global coverage of this data is also far from complete
(Hortal et al. 2007; Soberón et al. 2007), especially the spatial information on the relationship between geographical variation and fruit plant diversity in marginal lands. However, the potential uses for geographical data to test ecological hypotheses and describe nature are numerous (Guisan and Thuiller 2005; Pradhan 2019). The practical application of this geographical data is to develop conservation priority schemes for maintenance designs, which are explicitly directed at critical lands. One of the ecological data not available yet is the relationship of geographical variations to the biodiversity of fruit plant species, especially on marginal lands. Based on these problems, this study was carried out to determine the presence of fruit plant species richness sites in conservation success areas, analyze the relationship between diversity and locations, while also measuring the correlation between both (sites and diversity) to geographical variations in marginal land, in Jombang District, East Java Province, Indonesia.

\section{MATERIALS AND METHODS}

\section{Study area}

This study was conducted in Jombang District, East Java Province, from January-April 2019. The study location was determined by purposive sampling, which is one of the techniques using certain considerations (Fachrul 2007). Based on that, the location was determined by considering the conditions of vegetation density and geographical site, by making indirect visual observations using the Google Earth application, while also conducting surveys and direct visualizations. The map was generated with the $\mathrm{R}$ version 3.6.1 program, as shown in Figure 1.

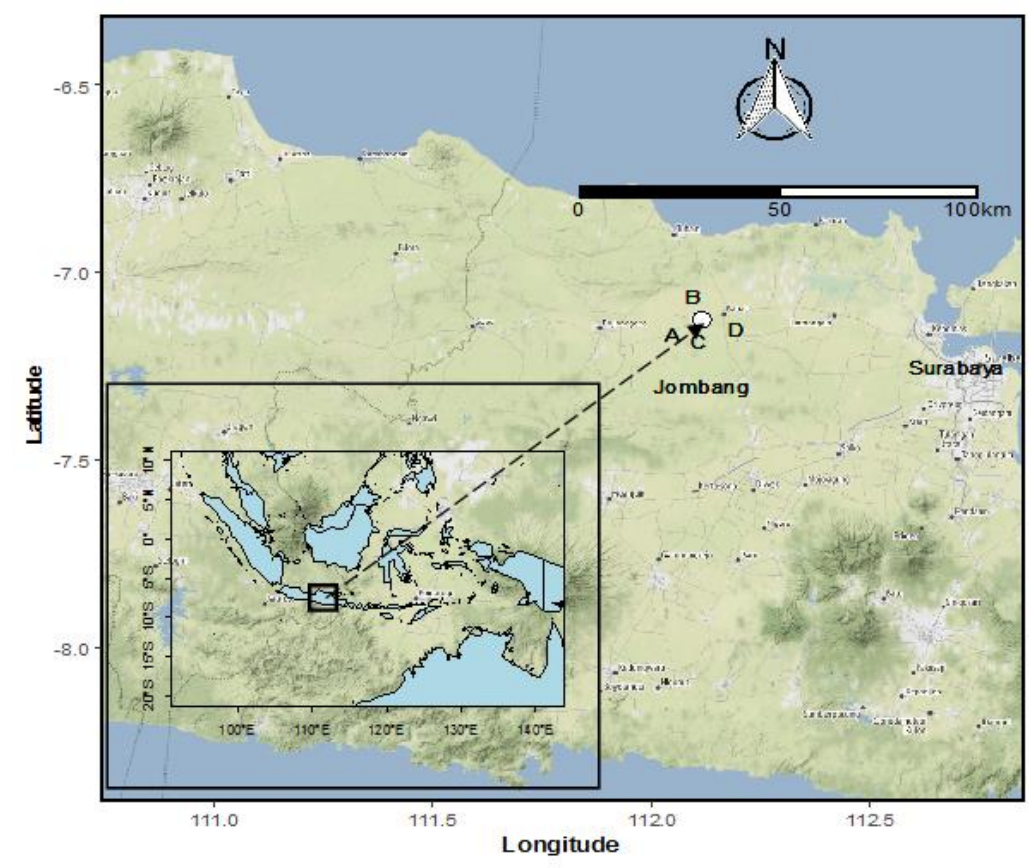

Figure 1. Map of study locations in Jombang District, East Java Province on 4 research sites, namely A. Plandaan Sub-district, B. Kabuh Sub-district, C. Ploso Sub-district, and D. Kudu Sub-district. Each site was taken as much as 2-3 samples at the village level. 


\section{Determination of the site locations}

Based on the general geographical appearance and vegetation thickness, 4 study sites $(A, B, C$, and $D)$ were determined and divided into eleven sub-locations with coordinates, slope, and ground height, as shown in Table 1.

An overview of the geographical variations of the study site on marginal land that has been planted with fruit trees is shown in Figure 2.

\section{Procedures}

The materials used in this research were yards and plantations, through which fruit tree biodiversity is developed by the community around the residential units (villages). The equipment used was rolling meter, rope, machete, measuring tape, pole, compass, meter, GPS, camera, field books, questionnaires, recording devices, and writing instruments. The research sample was obtained in the northern part of the Kapur Muda mountains at Kendeng, with horizontal and hilly physiology, including Plandaan, Kabuh, Ploso, and Kudu Sub-districts. Also, the sampling locations were each sub-district from the number of existing villages. Approximately $10 \%$ of the 53 villages were randomly assigned to the sample areas, therefore 11 residential units were obtained. The research targets were fruit tree owner household units, which were obtained by, (i) proportional random sampling in each village, and (ii) randomly assigning 11 units for field observations. Each unit then arranged a plot with a size of $20 \times 20 \mathrm{~m}^{2}$, which are substantial to 3 plots with a $10 \mathrm{~m}$ distance, as the transect length is $80 \mathrm{~m}$, as shown in Figure 3.

Table 1. Research locations of 11 sub-locations, coordinate positions, altitude and slope with each area used an area of $1,200 \mathrm{~m}^{2}$ as the research plot

\begin{tabular}{|c|c|c|c|c|c|c|}
\hline Sites & Village & Slope (\%) & $\begin{array}{c}\text { Elevation } \\
\text { (m asl.) }\end{array}$ & Latitude & Longitude & $\begin{array}{c}\text { Available land } \\
\text { area }\left(\mathbf{m}^{2}\right)\end{array}$ \\
\hline A1 & Bangsri & 23.5 & 68.00 & $07^{\circ} 27^{\prime} 21.3^{\prime \prime}$ & $112^{\circ} 10^{\prime} 41.6^{\prime \prime}$ & 56.000 \\
\hline A2 & Puri Semandeng & 23.5 & 68.00 & $07^{\circ} 27^{\prime} 21.1$ '” & $112^{\circ} 10^{\prime} 41.4^{\prime \prime}$ & 3.240 \\
\hline A3 & Gebang Bunder & 18.0 & 67.00 & $07^{\circ} 27^{\prime} 21.1$ '” & $112^{\circ} 10^{\prime} 42.5^{\prime \prime}$ & 4.000 \\
\hline B1 & Mangunan & 14.5 & 62.00 & $07^{\circ} 25^{\prime} 55.9 "$ & $112^{\circ} 13^{\prime} 10.2^{\prime \prime}$ & 3.650 \\
\hline B2 & Kabuh & 16.0 & 56.00 & $07^{\circ} 24^{\prime} 46.5^{\prime \prime}$ & $112^{\circ} 15^{\prime} 42.2^{\prime \prime}$ & 3.880 \\
\hline B3 & Karangpakis & 14.5 & 56.00 & $07^{\circ} 24^{\prime} 06.7^{\prime \prime}$ & $112^{\circ} 15^{\prime} 42.3^{\prime \prime}$ & 3.230 \\
\hline $\mathrm{C} 1$ & Pager Tanjung & 2.5 & 63.00 & $07^{\circ} 29^{\prime} 10.5^{\prime \prime}$ & $112^{\circ} 10^{\prime} 17.6^{\prime \prime}$ & 3.450 \\
\hline $\mathrm{C} 2$ & Kebon Agung & 2.25 & 62.00 & $07^{\circ} 28^{\prime} 55.8^{\prime \prime}$ & $112^{\circ} 10^{\prime} 33.8^{\prime \prime}$ & 4.700 \\
\hline $\mathrm{C} 3$ & Jati Banjar & 0.45 & 55.00 & $07^{\circ} 27^{\prime} 21.0^{\prime \prime}$ & $112^{\circ} 13^{\prime} 31.0^{\prime \prime}$ & 3.600 \\
\hline D1 & Sidokaton & 0.09 & 44.00 & $07^{\circ} 26^{\prime} 15.8^{\prime \prime}$ & $112^{\circ} 17^{\prime} 52.5^{\prime \prime}$ & 3.375 \\
\hline D2 & Randuwatang & 0.05 & 43.00 & $07^{\circ} 26^{\prime} 33.8^{\prime \prime}$ & $112^{\circ} 15^{\prime} 53.2^{\prime \prime}$ & 3.680 \\
\hline
\end{tabular}

Note: A: Plandaan sub-district, B: Kabuh sub-district, C: Ploso sub-district, D: Kudu sub-district
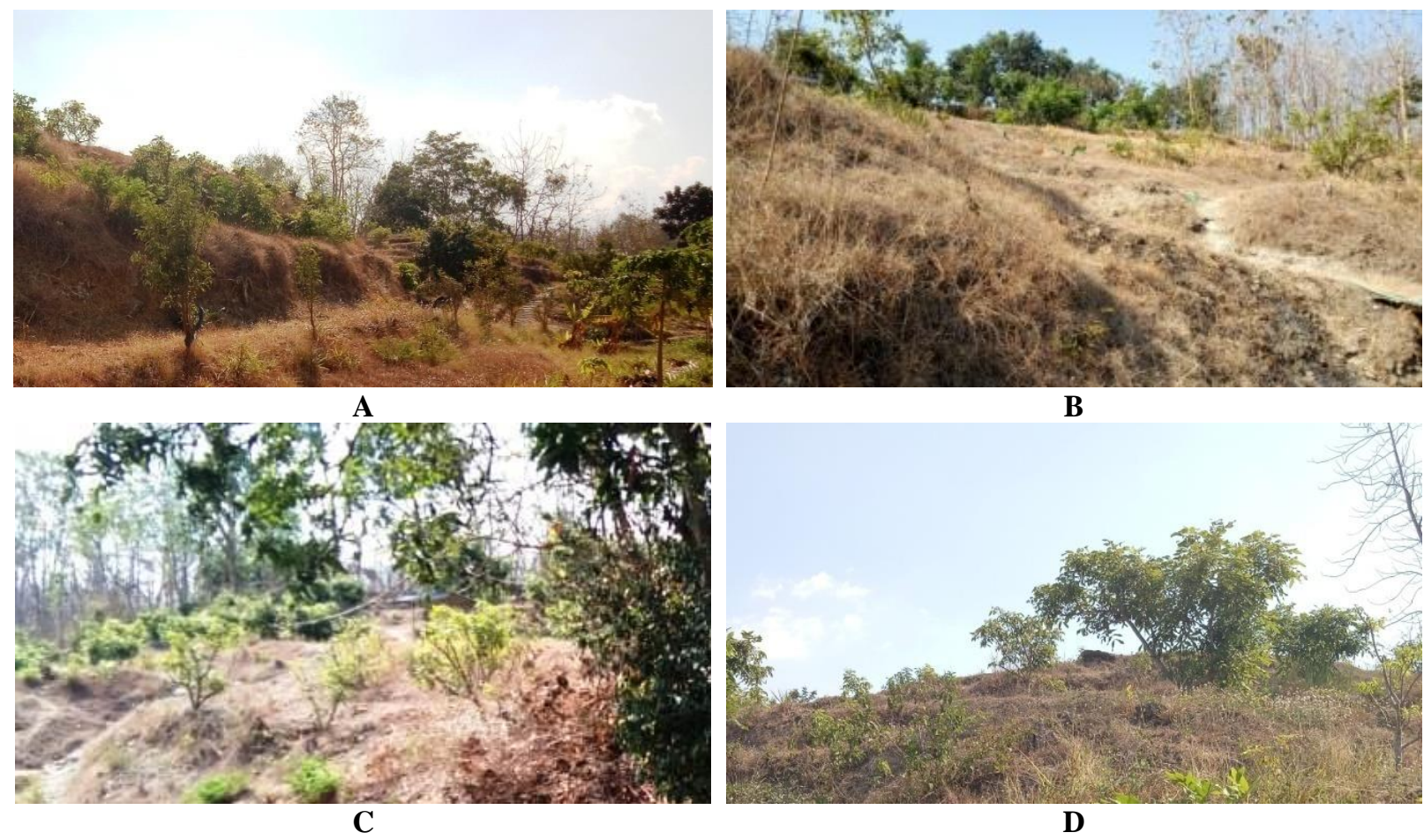

B

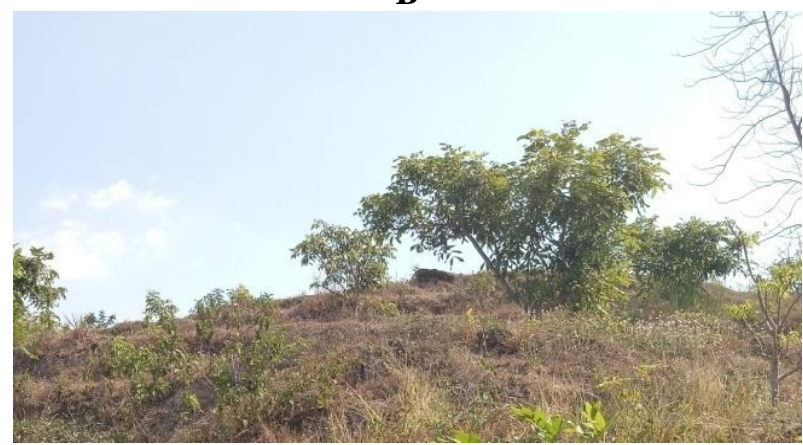

D

Figure 2. Geographical variation of the four study sites at the sub-district level, where site A has a slope range between 18-23.5\%, and an elevation between 67-68 m asl; site B has slope range between 14.5-16\%, and elevation between 56-62 m asl.; site C has slope range between 0.45-2.5\% and elevation between 55-63 m asl; and site D has slope range between 0.05-0.09\% and an elevation between 43-44 $\mathrm{m}$ asl. 


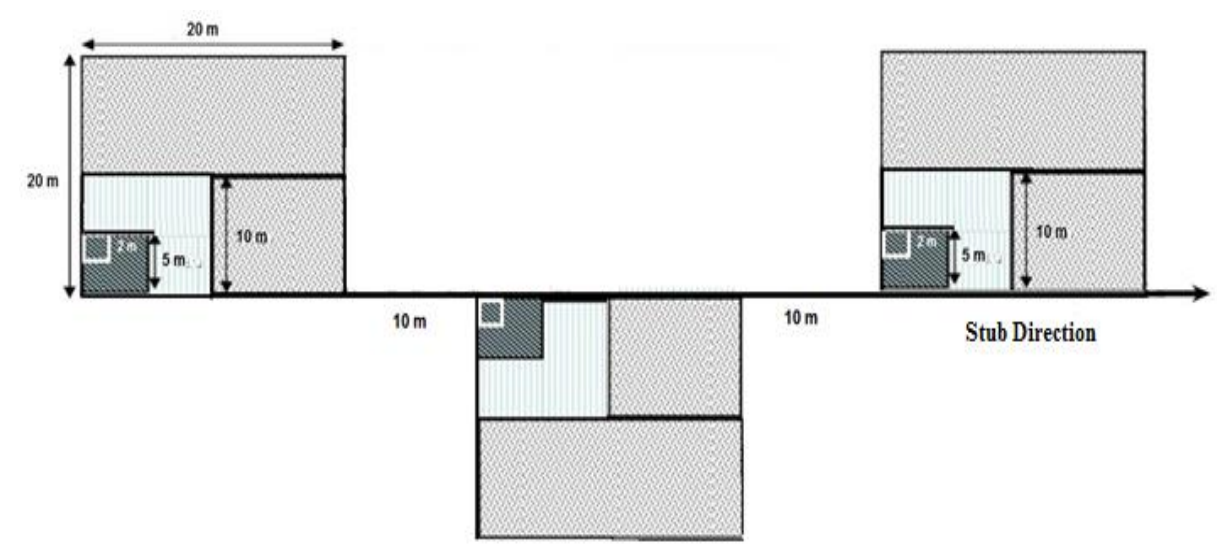

Figure 3. Making transect plots, sample plot sizes $20 \times 20 \mathrm{~m}^{2}$ (trees), $10 \times 10 \mathrm{~m}^{2}$ (poles) and $5 \times 5 \mathrm{~m}^{2}$ (stakes)

\section{Data analysis}

Multivariate analysis was formed in the BiodiversityR package ( Kindt and Coe 2005) of information that was imported from MS excel sheet format into R Commander GUI running on $\mathrm{R}$ 3.6.1 ( $\mathrm{R}$ Development Core Team 2012). Species density data collected from selected plots were initially converted to binomial presence/absence information, for use in one of the methods chosen for ordination and classification of vegetation (Smith 1993). After data transformation, the following ordination analysis methods were performed, using the Vegan (Oksanen et al. 2020) and MASS (Venables and Ripley 2002) packages: (i) Non-metric Multidimensional Scaling (NMDS) Analysis, (ii) Detrended Correspondence Analysis (DCA), (iii) Correspondence Analysis (CA) and Canonical Correspondence Analysis (CCA), (iv) Cluster Dendrogram Analysis.

The NMDS technique was used to observe community differences in an ordinate space, as it also handles species responses nonlinearity of any kind. Also, the unlimited ordination with NMDS (Clarke 1993) was used to visualize continuous variations in species composition and differences between plots and groups, which were identified by classification. Furthermore, the DCA technique was used to evaluate the similarities and differences in the floristic composition of vegetation samples, while the CA and CCA ordination analysis methods were carried out to determine the relationship between floristic and environmental data, namely elevation, slope, and temperature. The ordination results were also presented in the form of an ordination chart (Ali et al. 2015). The detrended correspondence analysis were also conducted in parallel, with results checked for conformity (Økland 1996). Based on being a method of limited ordination (ter Braak 1987), the Canonical Correspondence Analysis (CCA) used 11 plots to identify variations in local scale composition, which were explained by environmental variables. These variables described the geographical location (latitude, longitude) and terrain (slope, elevation, temperature) as terms of geographical variation (Franklin et al. 2015). Also, the Cluster Analysis was used for similarity to the observation group of the variables studied.

\section{RESULTS AND DISCUSSION}

Based on the three study objectives, the results included the determination of study sites on fruit tree richness, the relationship between geographical variations and locations, and the association between all variables (geographical variations, sites, and fruit tree richness).

\section{Effect of study sites on fruit plant species richness}

The results showed that the structure and composition of the vegetation in the 11 study sites were discovered to be 229 individual fruit plants, with a total of 21 species from 14 families. The fruit plant species with maximum abundance were Dimocarpus longan Lour (55 individuals) accompanied by Mangifera indica L, Pouteria sapota (Jacq.) H. E. Moore \& Steam, and Psidium guajava L. (50, 16, and 14 individuals). Based on the observed fruit plant families, the Sapindaceae, Anacardiaceae, Annonaceae, Myrtaceae, and Moraceae had 59, 52, 25, 23, and 9 individuals, respectively. The species richness of fruit plants growing on marginal lands determines biodiversity, due to being a simple indicator of biological variation, which is easy to interpret (Peet 1974). The species richness in the marginal land was dominated by $D$. longan and $M$. indica, due to the nature of these plants to grow in critical locations, therefore allowing them to be used as conservation crops. The knowledge of plant species richness and diversity was essential for understanding the structure of land communities, and also for planning and implementing population conservation strategies (Malik et al. 2014; Malik and Bhatt 2015). An understanding of land structure is a prerequisite for describing various ecological processes, and also for modelling functions and dynamics (Elourard et al. 1997). Also, the assessment of tree community composition and structure helps to understand plantation population status, regeneration, and diversity, for conservation purposes (Mishra et al. 2013).

Plant species diversity has also attracted particular attention, due to its significance to help determine current species performance and potential future community composition (Wang et al. 2006), while it also tends to show a decrease in fruit plant species variation on marginal 
lands. Plant species richness showed a statistically significant decline with higher grasslands soil quality in Germany (Martinuzzi et al. 2015). However, diversity is usually known as the relative distribution function of individuals among species. It is also governed by long-term factors, such as community stability and evolutionary timing due to the fact that the heterogeneity of microclimate affects diversification among different populations (Verma et al. 2004).

Based on the results of the analysis with the DCA ordination diagram, Karangpakis Village is in the upper left corner of the plot, was shown to have series of unique gradients, which in turn prevent it from sharing habitat with other sites. The sites of the Randuwatang, Kebon Agung, and Sidokaton villages at upper right side of the quadrant, showed good associations between each other, at a fairly low height and slope. The same thing was also shown in the lower left quadrant position, where Bangsri, Puri Semanding, Gebang Bunder, Mangunan, and Pager Tanjung sites showed good associations at high slope and altitude (Figure 4.A).

The DCA ordination diagram for the combined data between the site and the fruit plant showed that Cocos nucifera L, was in the upper right corner, shared habitat with Nephelium lappaceum L., and is well associated with the sites in Randuwatang, Kebun Agung, and Sidokaton villages. Based on the existence of fruit plants, the diagram showed that the sites in Karangpakis Village had good associations with Persea Americana, Mill, Artocarpus heterophyllous Lam, and D. longan L. Also, the uniqueness of fruit plants was shown in $T$. indica L. and $C$. nucifera L., which were in the lower-left and upper-right quadrants as rare crops, on the slopes with high and low altitudes, respectively (Figure 4.B).

A unique plant discovered on the medium plains and high slopes was $T$. indica L., due to its ability to grow quite well in marginal land. It was also discovered both in the wild and agricultural land. Also, 52 of the 60 acids (87\%) discovered in the squares grew among other plants or trees
(Ebifa-Otheieno et al. 2017). T. indica L. is a sustainable resource with positive environmental benefits, which has many available uses during the dry season, when supplies of other foods are low (Gunasena et al. 2000; Fichtl 2005), This plant provides perennial cover as protection for the soil, while also assisting in the storage and recycling of plant nutrients and organic matter (Gunasena et al. 2000; Morton 1987). T. indica L. also provides a valuable windbreak for homes and plants, due to its strong root system and flexible branches. The plant possesses strong roots and branches, wind resistance, highly resistant to disease, with the ability to grow successfully under a wide range of soil and agro-climatic conditions (Gunasena et al. 2000; Fichtl 2005; Morton 1987).

However, the significant characteristic of $C$. nucifera species, is the ability to grow in high temperature and lowland conditions (Malik et al. 2014).

Based on the CA analysis, the classification of study sites showed that the Sidokaton, Randuwatang, and Kebon Agung villages were included in group 1, followed by the Karangpakis location in 2, with Bangsri, Puri Semanding, Gebang Bunder, Mangunan, Kabuh, Pager Tanjung, and Jati Banjar regions in 3 (Figure 5A). The site grouping was strengthened by the results of the Dendrogram cluster analysis, which was divided into three groups (Figure 5B). Even though the Karangpakis village site had a high slope and altitude, it also had different characteristics from group 3 , with group 1 tending to have a fairly low terrain and height. The results of the analysis also confirmed that there was a distribution pattern of fruit plant growth in the eleven sites studied on marginal land, which was formed from its relationship with variations in slope, and elevation. This indicated that fruit plants were discovered in hilly areas, as there were seven sites located in this region. Furthermore, species richness tends to increase with increasing altitude, which creates a "bulge" of diversity in the middle range height and then decreases again. Therefore, the altitude affect represented a "hump-shaped" gradient (Grytnes 2003; Rahbek 2005; McCain 2005; Wang and Fang 2012).

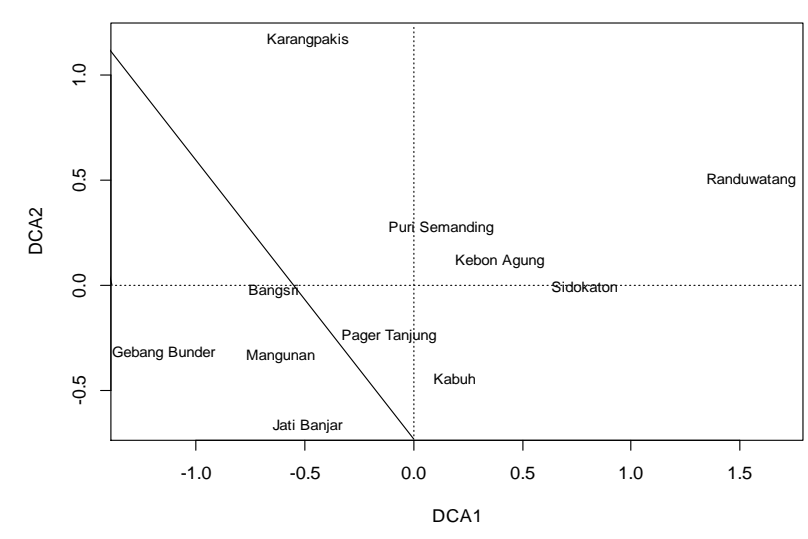

A

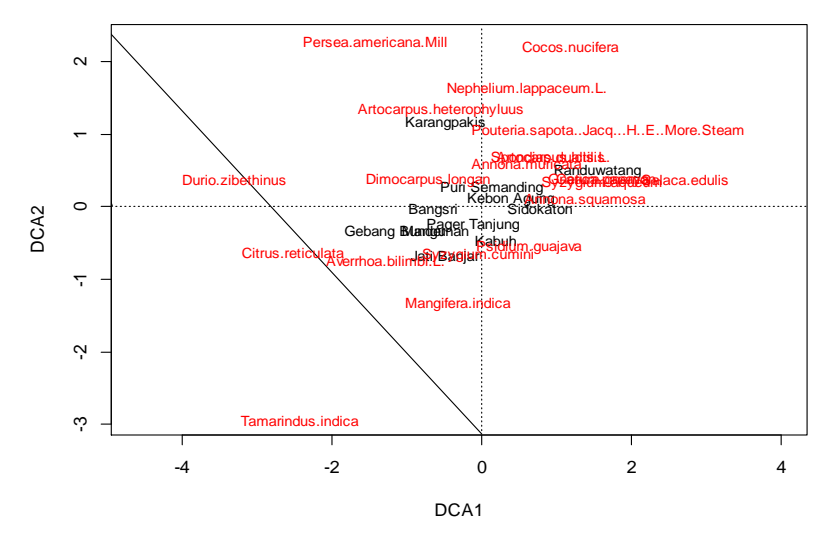

B

Figure 4. The DCA ordination plot of research sites from eleven villages that exist in the marginal land location (A) and the plot between the sites and the presence of fruit plants (B), where the sites are shown in black and fruit plants in red 


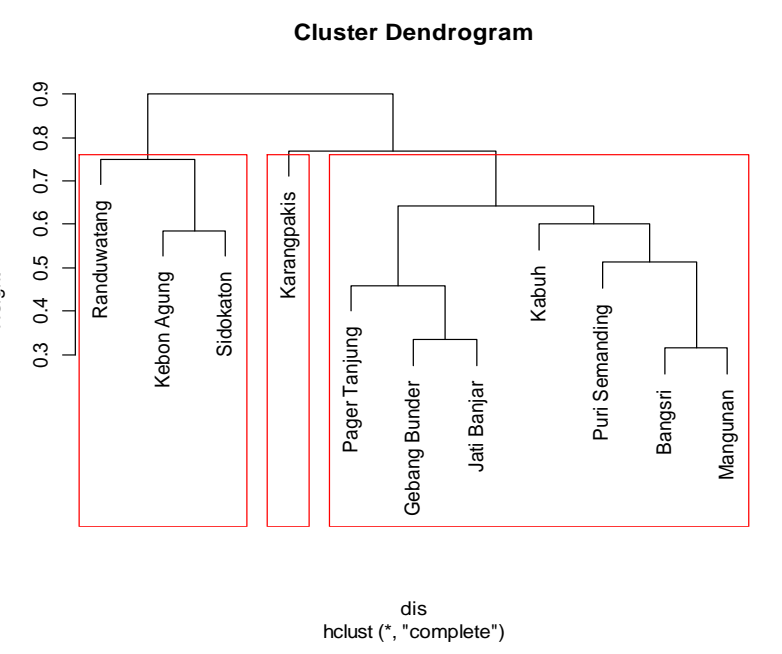

A

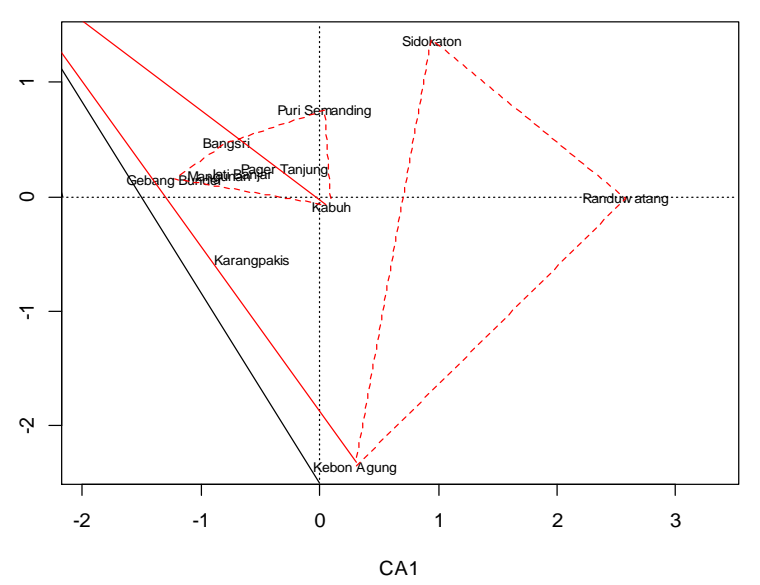

B

Figure 5. Cluster Dendrogram Analysis of study locations from eleven villages that exist in marginal land locations (A) and CA analysis between location and existence of fruit trees (B).

Also in this study, three sites observed on the low slope and elevation seemed to be flat, therefore providing a variety of fruit plant species that grow on the land, while forming a distribution pattern of diversity. This was in line with the opinion of Kratochwil (1999), which stated that the distribution pattern of plant species diversity was a synthetic reflection of all types of ecological gradients. The study also stated that the pattern of biodiversity along environmental gradients was one of the main problems in biological variation research, which affected the slope and elevation diversities of land. The study of plant species diversity patterns and the ecological factors influencing them, forms the basis of conservation biology (Noss et al. 1999), especially in shaping the nature of marginal land communities.

\section{Relationship between slope, altitude, and temperature on site and combination model}

The results of the NMDS test showed that geographical variations had a significant relationship with fruit plant sites, as the slope and altitude provided correlation values $\left(\mathrm{r}^{2}\right)$ of 0.5889 and 0.5077 , at the level of $(\alpha) 0.05$, respectively (Table 2). Based on the direction and relationship strength between geographical variations and fruit plant diversity sites, it was observed that slope and elevation had the same route, as shown in Figure 6. Moreover, this relationship determined the nature of the land community. The nature of marginal land communities is highly dependent on the ecological characteristics of the location, species diversity, and the status of fruit plant regeneration. Quantitative information on the composition, distribution, and abundance of fruit plant species is also a key to understanding the shape and structure of marginal land communities, with the planning and implementation of community conservation strategies. Species richness and plant diversity are also fundamental to land biodiversity, as trees provided resources and habitat for nearly all other terrestrial species (Malik 2014). As regards marginal land ecosystems, trees were responsible for the overall physical structure of the habitat as a form of survival, as they also defined the place fundamentally for structural complexity and environmental heterogeneity (Malik et al. 2016).

The arrow direction was indicated by a negative sign on the slope and altitude, as the positive route of the temperature and relationship strength were at NMDS1, where the elevation had greater power of 0.91516, compared to the slope at 0.83353 . Also, the temperature had a relationship strength value of 0.71254 at NMDS2, which is observed to be lower than the slope and elevation.

In Figure 6, it was observed that the vector formation from geographical variation had three arrows, where those formed from elevation were longer than the ones obtained from the slope and temperature. This clearly showed that elevation had a greater relationship strength than slope and temperature. Based on the direction of the relationship, it further showed that the slope and height had similar route, and are different from the temperature.

This indicated that the increasing value of the slope and the height, had a relationship with the decreasing parameter of the temperature. Also, the temperature had a relationship with the moisture level of the plant's growing environment. Moisture, especially present in the soil, is the ecological factor most closely related to vegetation growth (Körner 1999), and there is a positive correlation between elevation gradient and groundwater content (Zhuang et al. 2012). Zhang et al. (2010), also emphasized that the composition of the community was generally sensitive to local environmental conditions, such as soil chemistry, topography, sunlight, and atmospheric humidity.

Table 2. Non-metric Multidimensional Scaling (NMDS) Test of Fruit Plant Sites with Geographical Environment

\begin{tabular}{|c|c|c|c|c|}
\hline $\begin{array}{c}\text { Environmental } \\
\text { factor }\end{array}$ & NMDS1 & NMDS2 & $\mathbf{r}^{2}$ & $\operatorname{Pr}(>\mathbf{r})$ \\
\hline Slope & -0.83353 & -0.55248 & 0.5889 & $0.028 *$ \\
\hline Elevation & -0.91516 & 0.40309 & 0.5077 & $0.049 *$ \\
\hline Temperature & 0.70163 & 0.71254 & 0.3264 & 0.200 \\
\hline Signif.codes & \multicolumn{4}{|c|}{0 '***' $0.001^{\prime * * '} 0.01^{\prime * \prime} 0.05^{\prime} . .^{\prime} 0.1^{\prime \prime}{ }^{\prime} 1$} \\
\hline
\end{tabular}




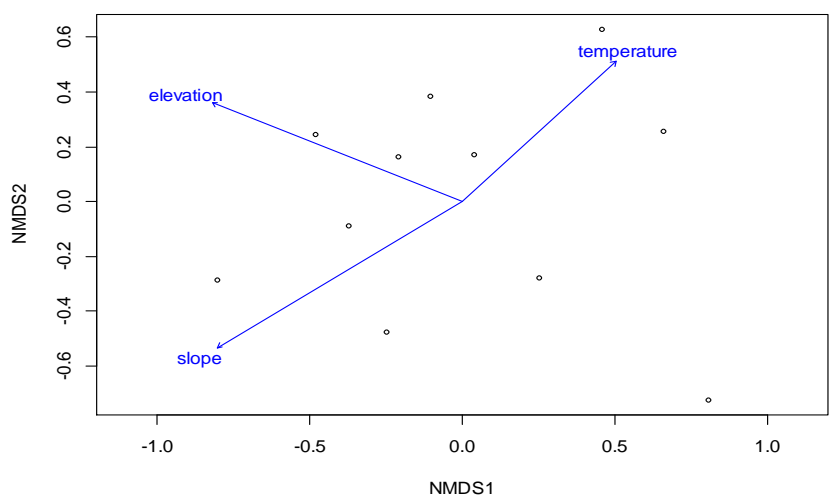

Figure 6. The direction and relationship strength between geographical factors that influenced the results of the NMDS test on the site and fruit plant diversity, included variations in slope, elevation, and temperature.

In the NMDS test, when the response and vector were truly linear and appropriate, respectively, the surface installed was a plane with parallel gradient to the arrow. Also, the contours installed were equally spaced with parallel lines, which were perpendicular to the arrow as well. Furthermore, the test results showed that the response formed was not linear, as the suitability of the vector from the mounted surface formed a plane whose gradient was not completely parallel to the arrow. Also, the contours installed with parallel lines were not perpendicular to the arrow, and seemed to provide smooth linear lines (Figure 7). Figure 7.A also showed that the elevation formed a nonlinear response, as this was indicated by the gradient line which is not perpendicular to the parallel contour lines, with a smooth outline. Moreover, the same cases were also shown for the slope (Figure 7.B) and temperature (Figure 7.C). This showed that the response to geographical variations in slope, elevation, and temperature, provided a non-linear relationship. This condition further indicated that the response of geographical variations, such as slope, elevation, and temperature to fruit plant sites was not linear, due to the natural heterogeneity of the locations and the spatial distribution of individual species (Williamson et al. 2002; Dengler 2009).

The response formed between geographical variations and sites was not linear from the corresponding vector, which is indicated by a high $\mathrm{D}^{\wedge} 2$ value, as it does not form a straight line and intersect perpendicularly to the vector direction. The direction and relationship strength between the various models of slope, elevation, and temperature showed that terrain and height had a strong association, as evident from greater GCV score of 48.47885 (Figure 8.A). This result was relatively high, compared to both the slope and elevation models with temperature at similar GCV values of 0.1387292 , respectively (Figures 8.B and 8.C).

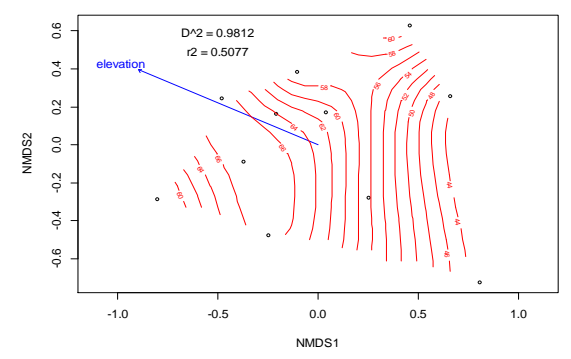

A

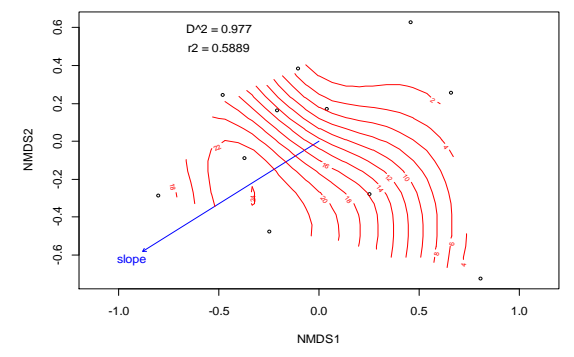

B

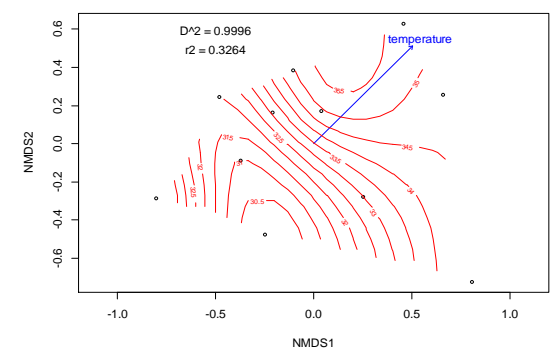

C

Figure 7. Nonlinear response of the relationship formed from the site and to the slope $\mathrm{D}^{\wedge} 2=0.9811$ (A), elevation $\mathrm{D}^{\wedge} 2=0.9811(\mathrm{~B})$ and temperature $\mathrm{D}^{\wedge} 2=0.9996(\mathrm{C})$ with smoother contour lines. Constructed contour lines of site variations are shown in red and arrows as vectors of geographic variations are shown in blue

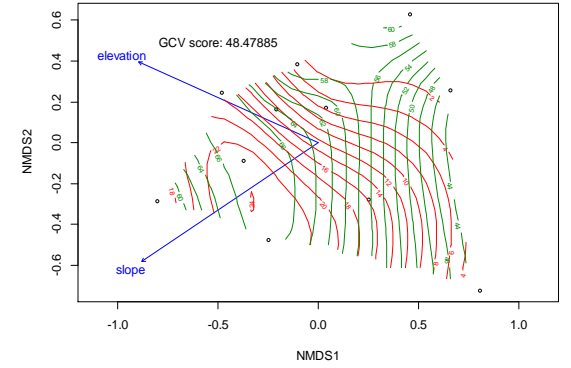

A

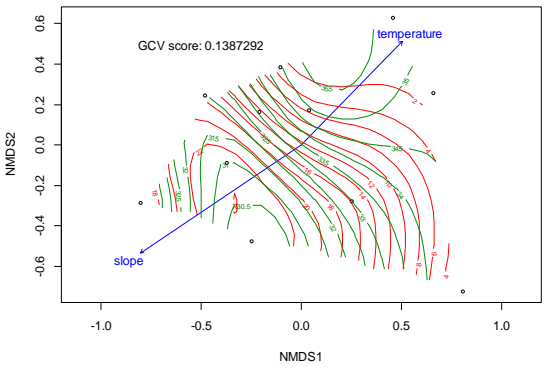

B

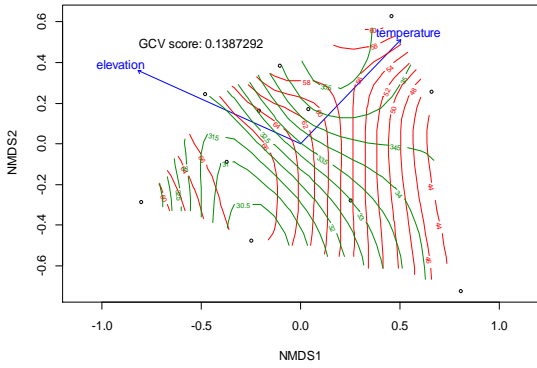

C

Figure 8. The relationship model that was formed from geographical variations with fruit plant species from 11 sites that were observed with smooth contour lines and responses is non-linear. Fruit plant diversity model with slope and elevation (red slope contour line, green elevation) (A), slope (red contour line) and temperature (green contour line) (B), and elevation (red contour line) with temperature (line green contour) $(\mathrm{C})$ 
Also, a non-linear relationship was shown between fruit plant sites and geographical factors, with slope and elevation having a strong influence over temperature. This result was in line with the study of Beccera' (2016), which suggested that species richness was related to geographical gradients of latitude and altitude, with climatic factors, particularly rainfall and relative humidity, observed to influence this pattern. However, temperature is likely to affect the species richness of fruit plants in this area.

Geographical variables are related to several abiotic factors, such as drainage conditions and nutrient flow, and based on being important determinants for species diversity, they show multidimensional and multi-scale effects on plant variation patterns (Zuazo et al. 2011). The physical properties of phytochemicals and the parent material of the soil, affect plants that grow on marginal lands and other species diversity (Wang et al. 2002). Also, the elevation gradient is a key factor shaping different environmental habitats, and contains large-scale variations of many direct ecological factors, such as temperature, humidity, sunlight, and soil properties, which affect the distribution and structure of plant communities and species diversity. The variation in plant species diversity should be attributed to several ecological gradients (Chawla et al. 2008), as the elevation gradient is one of the determinants shaping the spatial variation patterns (Wang et al. 2002).

\section{Relation of geographic variation, site and fruit plant diversity}

Based on the ANOVA CCA test, the relationship between slope, elevation, and temperature variations on the site and fruit plants diversity, formed a very significant model with a $\operatorname{Pr}$ value $(>F)$ of 0.004 at the $(\alpha) 0.001$ level. This showed that the model formed was acceptable, which in turn indicates that there is a relationship between geographical variations (slope, elevation, and temperature) with sites and fruit plant diversity (Table 3 ).

To recognize the extent this model is likely to be accepted against the factors forming geographical variation, slope, elevation, and temperature formed a significant model with a Pr value (> F) of 0.041, 0.006, and 0.086 , at the level $(\alpha) 0.01,0.001$, and 0.05 , respectively (Table 4). This showed that the factors formed from geographical variations should be accepted as models, as slope, elevation and temperature provided a significant relationship to the sites and fruit plants species richness. Also, the growth of fruit plants at the population level is highly correlated with the geographical conditions and the sites of the plantation. Furthermore, at the individual level, this correlation was obtained from plants with the highest growth, resulting in the determination of population yields with low fruit production. These results differ from previous studies on fruit plants, which observed that weather conditions (temperature and rainfall) had no impact (Sperens 1997; Wallenius 1999), or had very weak effects (Kobro et al. 2003).

Based on the axis-based ANOVA CCA analysis, it showed that CCA1 should be accepted significantly, due to the provision of a $\operatorname{Pr}$ value $(>F)$ of 0.004 , at the $(\alpha) 0.001$ level (Table 5). This further indicated that the relationship model built from geographical variations, sites, and fruit plant diversity was represented on the CCA1 axis.

The significant results of CCA analysis on the CCA1 axis indicated that the sites that were associated well at high temperatures were Sidokaton and Randuwatang villages, with the presence of $C$. nucifera, $P$. americana, and Salacca zalacca (Gaertn) Voss fruit plants, as shown in Figure 9. Also, sites associated quite well on high slopes and elevations were Puri Semanding, Bangsri, Gebang Bunder, and Mangunan villages. The fruit plants adequately growing and associated with these areas were Durio zibethinus L., Syzygium cumini (L.) Skeels, Citrus reticulata Blanca, $T$. indica, and D. longan.

From the results, it was observed that there was a correlation between temperature and moisture level of the plants' growing environment. Soil moisture was also observed as the ecological factor most closely related to vegetation growth (Körner 1999). Also, there was a negative correlation between temperature with elevation and slope. This was in line with the results of previous studies, which showed a positive correlation between elevation gradient with decreasing temperature, and increasing groundwater content (Zhuang, et al. 2012). Fruit species richness was also discovered to be positively and negatively related to latitude and altitude, respectively. Furthermore, it was positively related to annual rainfall and relative humidity of the atmosphere, and negatively associated with the mean winter minimum temperature. Moreover, rainfall increased with latitude, and winter minimum temperatures decreased with altitude (Beccera 2016).

Table 3. The results of ANOVA CCA test of the model slope, elevation and temperature on sites and fruit plant.

\begin{tabular}{|c|c|c|c|c|}
\hline & Df & ChiSquare & $\mathbf{F}$ & $\operatorname{Pr}(>\mathbf{F})$ \\
\hline Model & 3 & 0.78972 & 1.7357 & $0.004 * *$ \\
\hline Residual & 7 & 1.06165 & & \\
\hline Signif. Codes: & \multicolumn{4}{|c|}{0 '***' 0.001 '**' 0.01 '*' 0.05 '.' 0.1 ' ' 1} \\
\hline
\end{tabular}

Table 4. The results of CCA ANOVA Test (mod, by = "term", step $=200$ )

\begin{tabular}{lllll}
\hline & Df & ChiSquare & F & $\operatorname{Pr}(>\mathbf{F})$ \\
\hline Slope & 1 & 0.23344 & 1.5392 & $0.041^{*}$ \\
Elevation & 1 & 0.29020 & 1.9128 & $0.006^{* *}$ \\
Temperature & 1 & 0.26618 & 1.7551 & $0.086^{\cdot}$ \\
Residual & 7 & 1.06165 & & \\
Signif. Codes & $0^{\prime * * * \prime} 0.001^{\prime * * \prime} 0.01^{\prime * \prime} 0.05^{\prime \cdot{ }^{\prime}} 0.1^{\prime \prime} 1$ \\
\hline
\end{tabular}

Table 5.The results of ANOVA CCA Test (mod, by = "axis", perm $=1000$ )

\begin{tabular}{lllll}
\hline & Df & ChiSquare & F & $\operatorname{Pr}(>\mathbf{F})$ \\
\hline CCA1 & 1 & 0.37249 & 2.4560 & $0.004 * *$ \\
CCA2 & 1 & 0.22577 & 1.4886 & 0.356 \\
CCA3 & 1 & 0.19146 & 1.2624 & 0.279 \\
Residual & 7 & 1.06165 & & \\
Signif. Codes: & $0^{\prime * * * '} 0.001^{\prime * *} 0.01^{\prime * \prime} 0.05^{\prime \cdot \prime^{\prime}} 0.1^{\prime \prime} 1$ \\
\hline
\end{tabular}




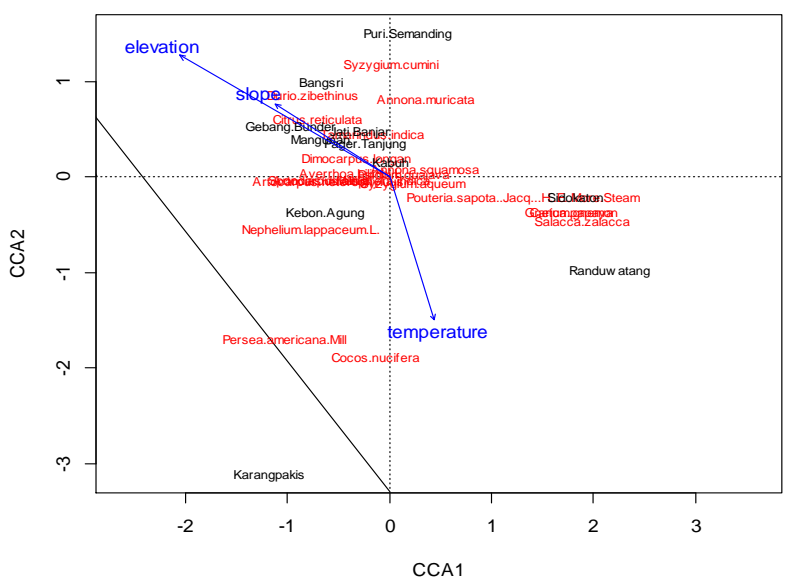

Figure 9. Ordination results of Canonical Correspondence Analysis (CCA), with a significance level of $\mathrm{P}(>\mathrm{F})=0.004$ at the 0.01 level, was shown in the form of ordinated triplot charts of the relationship between sites, geographical conditions and fruit plant species richness. Vector shapes based on the arrow direction and length represented geographical variations were shown in blue, sites were indicated with black, and fruit plant species were represented in red.

In this research, conclusion showed that there was a distribution pattern of fruit plant growth in the eleven sites of marginal land, which formed a significant relationship with variations in slope, elevation and temperature. There were three sites at high temperature with low slopes and elevation, possessing a value range of $0.05-2.5 \%$ and $43-55$ $\mathrm{m}$ asl., respectively. The remaining sites were at low temperatures with high slope and elevation, at $14.5-23.5 \%$ and 56-68 $\mathrm{m}$ asl., respectively. Besides that, there was a location with different geographical characteristics from the sites in this area. Generally, it was also observed that fruit plants growing on marginal land were often discovered in hills, due to the fact that there were seven of those sites in this area. However, there were three sites with the slope and low elevation low variety of fruit species. The analysis of geographical variation also showed that slope and elevation were significantly correlated with sites with species richness, except temperature. Also, the responses formed from these relationships were not linear, due to the site heterogeneity. Among the 21 fruit plant speciesobserved, two unique breeds were discovered, due to their adaptability to critical land environments. The uniqueness of fruit plants was also shown in $T$. indica and C. nucifera, as rare plants on slopes with high and low elevations.

\section{ACKNOWLEDGEMENTS}

This study is a part of a dissertation of the first author. Financial support was received from the BPPDN (Domestic Postgraduate Education Scholarship) program by the Ministry of Education and Culture in 2017. Also, the authors are grateful to the ecology laboratory, for providing practical tools, in order for this study to be a success.

\section{REFERENCES}

Ali K, Khan N, Rahman IU, Ahmad H, Jury S. 2015. Multivariate analysis and vegetation mapping of a biodiversity hotspot in the Hindu Kush Mountains. Intl J Adv Res 3: 990-1006

Allen AP, Brown JH, Gillooly JF. 2002. Global biodiversity, biochemical kinetics, and the energetic-equivalence rule. Science 297: 1545-1548. DOI: $10.1126 /$ science. 1072380

Beccera, P I. 2016. Relationship between climate and geographical variation of local woody species richness within the Mediterraneantype region of Chile. Rev Chilena Hist Nat 89: 12 DOI 10.1186/s40693-016-0062-x.

Chawla A, Rajkumar S, Singh KN, Lal, B, Singh RD, Tkukraj AK. 2008. Plant species diversity along an altitudinal gradient of Bhabha Valley in Western Himalaya. J Mt Sci 5: 157-177. DOI: 10.1007/s11629008-0079-y

Cincotta RP, Wisnewski J, Engelman R. 2000. Human population in the biodiversity hotspots. Nature 404: 990-992. DOI: 10.1038/35010105

Clarke KR. 1993. Non-parametric multivariate analyses of changes in community structure. Aust J Ecol 18: 117-143 DOI: 10.1111/j.14429993.1993.tb00438.x.

Dengler J. 2009. Which function describes the species-area relationship best? A review and empirical evaluation. J Biogeogr 36: 728-744. DOI: 10.1111/j.1365-2699.2008.02038.x.

Ebifa-Othieno E, Mugisha A, Nyeko P, Kabasa JD. 2017. Knowledge, attitudes and practices in tamarind (Tamarindus indica L.) use and conservation in Eastern Uganda. J Ethnobio Ethnomed 13: 5. DOI: 10.1186/s13002-016-0133-8.

Elourard C, Pascal JP, Pelissier R, Ramesh BR., Houllier F, Durand M. 1997. Monitoring the structure and dynamics of a dense moist evergreen forest in the Western Ghats (Kodagu District, Karnataka, India). Trop Ecol 38: 193-214.

Evans KL, van Rensburg BJ, Gaston KJ, Chown SL. 2006. People, species richness and Human population growth. Global Ecol Biogeogr 15: 625-636. DOI:10.1111/j.1466-8238.2006.00253.x

Fachrul MF. 2007. Metode Sampling Bioekologi. Bumi Aksara. Jakarta, Indonesia. [Indonesian]

Ferrer-Castán D, Vetaas OR. 2005. Pteridophyte richness, climate and topography in the Iberian Peninsula: comparing spatial and nonspatial models of richness patterns. Glob Ecol Biogeogr 14: 155-165. DOI: 10.1111/j.1466-822X.2004.00140.x.

Field R, O’Brien EM, Whittaker RJ. 2005. Global models for predicting woody plant richness from climate: development and evaluation. Ecology 86: 2263-2277. DOI: 10.1890/04-1910.

Flather CH., Wilson KR, Shriner SA. 2009. Geographic approaches to biodiversity conservation: implications of scale and error to landscape planning. In: Millspaugh JJ, Thompson FR (eds). Models for Planning Wildlife Conservation in Large Landscapes. Elsevier, Amsterdam.

Franklin J, Ripplinger J, Freid EH, Marcano-Vega H, Steadman DW. 2015. Regional variation in Caribbean dry forest tree species composition. Plant Ecol 216: 873-886. DOI: 10.1007/s11258-0150474-8.

Gedan KB, Bertness MD. 2009. Experimental warming causes rapid loss of plant diversity in New England salt marshes. Ecol Lett 12: 842848. DOI: $10.1111 /$ j.1461-0248.2009.01337.x

Gaston KJ. 2000. Global patterns in biodiversity. Nature 405:220-227. DOI: $10.1038 / 35012228$.

Gaston KJ. 2006. Biodiversity and extinction: Macroecological patterns and people. Prog Phys Geogr 30: 258-269. DOI: 10.1191/0309133306pp483pr.

Gaston KJ, Quinn RM, Blackburn TM, Eversham BC. 1998. Species-Range Size Distributions in Britain. Ecograph. 21: 361-370. DOI: 10.1111/j.1600-0587.1998.tb00401.x.

Grytnes JA. 2003. Species-richness patterns of vascular plants along seven altitudinal transects in Norway. Ecography 26: 291-300. DOI: 10.1034/j.1600-0587.2003.03358.x.

Guisan A, Thuiller W. 2005. Predicting species distribution: Offering more than simple habitat models. Ecology Letters 8: 993-1009. DOI: 10.1111/j.1461-0248.2005.00792.x.

Gunasena HPM, Hughes A, Haq N, Smith RW. 2000. Tamarind: Tamarindus indica L. International Centre for Underutilised Crops, University of Southampton, UK.

Hortal J, Lobo JM, Jime'nez-Valverde A. 2007. Limitations of biodiversity databases: Case study on seed-plant diversity in Tenerife, 
Canary Islands. Conserv Biol 21: 853-863. DOI: 10.1111/j.15231739.2007.00686.x.

Imhoff ML, Bounoua L, Ricketts T, Loucks C, Harriss R, Lawrence WT. 2004. Global patterns in human consumption of net primary production. Nature. 429: 870-873. DOI: 10.1038/nature02619.

Jetz W, Rahbek C. 2001. Geometric constraints explain much of the species richness pattern in African birds. Proc Nat Acad Sci 98: 56615666. DOI: 10.1073/pnas.091100998.

Kindt R, Coe R. 2005. Tree diversity analysis. A manual and software for common statistical methods for ecological and biodiversity studies. Word Agroforestry Centre (ICRAF), Nairobi.

Kluge J, Kessler M, Dunn RR. 2006. What drives elevational patterns of diversity? Atest of geometric constraints, climate and species pool effects for pteridophytes on an elevational gradient in Costa Rica Glob Ecol Biogeogr 15: 358-371. DOI: 10.1111/j.1466822X.2006.00223.X.

Kobro S, Søreide L, Djønne E, Rafoss T, Jaastad G, Witzgall P. 2003. Masting of rowan Sorbus aucuparia L. and consequences for the apple fruit moth Argyresthia conjugella Zeller. Popul Ecol 45: 25-30. DOI: 10.1007/s10144-003-0136-x.

Körner C. 1999. Alpine Plant Life: Functional Plant Ecology of High Mountain Ecosystems. Springer-Verlag, Berlin. DOI: 10.1007/978-3642-18970-8.

Kratochwil A. (ed). 1999. Biodiversity in ecosystems: principles and case studies of different complexity levels (Tasks for Vegetation Science). Springer, Netherlands. DOI: 10.1007/978-94-011-4677-7.

Ludwig JA, Reynolds JF. 1988. Statistical Ecology: A Primer on Methods and Computing. John Wiley \& Sons. Inc., New York.

Malik ZA. 2014. Phytosociological behaviour, anthropogenic disturbances and regeneration status along an altitudinal gradient in Kedarnath Wildlife Sanctuary (KWLS) and its adjoining areas. [thesis]. HNB Garhwal University Srinagar, Garhwal, Uttarakhand.

Malik ZA, Hussain A, Iqbal K, Bhatt AB. 2014. Species richness and diversity along the disturbance gradient in Kedarnath Wildlife Sanctuary and its adjoining areas in Garhwal Himalaya, India. Intl $\mathbf{J}$ Curr Res 6: 10918-10926.

Malik ZA, Bhatt AB. 2015. Phytosociological analysis of woody species in Kedarnath Wildlife Sanctuary and its adjoining areas in Western Himalaya, India. J For Environ Sci 31 (3): 149-163. DOI: 10.7747/JFES.2015.31.3.149

Malik ZA, Pandey R, Bhatt AB. 2016. Anthropogenic disturbances and their impact on vegetation in Western Himalaya, India. J M Sci 13: 69-82. DOI: 10.1007/s11629-015-3533-7.

Martinuzzi S, Withey JC, Pidgeon AM, Plantinga AJ, McKerrow AJ, Williams SG, et al. 2015. Future land-use scenarios and the loss of wildlife habitats in the southeastern United States. Ecol Appl 25: 160-171 DOI: 10.1890/13-2078.1.

Mishra AK, Behera SK, Singh K, Mishra RM, Chaudhary LB, Singh B. 2013. Effect of abiotic factor on understory community structures in moist deciduous forest of northern India. For Sci Pract 15: 261-273. DOI: $10.1007 / \mathrm{s} 11632-013-0415-3$.

McCain CM. 2005. Elevational gradients in diversity of small mammals. Ecology 86: 366-372. DOI: 10.1890/03-3147.

Morton JF. 1987. Fruits of warm climates. Creative Resources Systems. Inc., Winterville, NC.

Myers N, Mittermeier RA, Mittermeier CG, Da Fosenca GAB, Kent J. 2000. Biodiversity hotspots for conservation priorities. Nature 403 : 853-858. DOI: $10.1038 / 35002501$.

Noss RF, Dinerstein E, Gilbert B, Gilpin M, Miller BJ, Terborgh J, Trombulak S. 1999. Core areas: Where nature reigns. In: Soul'e ME, Terborgh J (eds). Continental Conservation: Scientific Foundations of Regional Reserve Networks. Island Press, Washington, D.C., USA.

Odling-Smee L. 2005. Dollars and sense. Nature 437: 614-616, DOI: $10.1038 / 437614 \mathrm{a}$.

O’ Brien EM, Field R, Whittaker RJ. 2000. Climatic gradients in woody plant (tree and shrub) diversity: water-energy dynamics, residual variation, and topography. Oikos. 89: 588-600 DOI: 10.1034/j.16000706.2000.890319.x

Peet R.K. 1978. Forest vegetation of Colorado Front Range: patterns of species diversity. Vegetatio 37: 65-78. DOI: 10.1007/BF00126830.

Pradhan P. 2019. Testing equivalency of interpolation derived bioclimatic variables with actual precipitation: A step towards selecting more realistic explanatory variables for Species Distribution Modelling. Res J Chem Environ 23 (12): 38-41.
Qian H. 1999. Spatial pattern of vascular plant diversity in North America north of Mexico and its floristic relationship with Eurasia. Ann Bot 83: 271-283. DOI: 10.1006/anbo.1998.0816.

Økland RH. 1996. Are ordination and constrained ordination alternative or complementary strategies in general ecological studies? J Veg Sci 7(2): 289-292. DOI: $10.2307 / 3236330$

Oksanen J, Guillaume Blanchet F, Friendly M, Kindt R, Legendre P, McGlinn D. 2020. Vegan: Community Ecology Package. R package version 2.5-7. https://CRAN.R-project.org/package=vegan

R Development Core Team, 2012. R: a language and environment for statistical computing. R Foundation for Statistical Computing, Vienna. http://www.R-project.org.

Rahbek C. 2005. The role of spatial scale and the perception of large-scale species richness patterns. Ecol Lett 8: 224-239. DOI: 10.1111/j.1461461-0248.2004.00701.x.

Peet RK. 1974. The measurement of species diversity. Ann Rev Ecol Syst 5: 285-307 DOI: 10.1146/annurev.es.05.110174.001441

Reid WV. 1998. Biodiversity hotspots. Trend Ecol Evol 13: 275-280. DOI: $10.1016 / \mathrm{S} 0169-5347(98) 01363-9$.

Ricklefs RE, Qian H, White PS. 2004. The region effect on mesoscale plant species richness between eastern Asia and eastern North America. Ecography 27: 129-136. DOI: 10.1111/j.09067590.2004.03789.x.

Rosenzweig ML. 1995. Species diversity in space and time. Cambridge University Press, UK. DOI: 10.1017/CBO9780511623387.

Sala O, Chapin FS III, Armesto JJ, Berlow E, Bloomfield J, Dirzo R, Elisabeth HS, Laura FH, Robert BK, Ann K, Rik L, David ML, Harold AM, Martín O, LeRoy PN, Martin TS, Brian HW, Marilyn W Diana HW. 2000. Global biodiversity scenarios for the year 2100 . Science 287: 1770-1774. DOI: 10.1126/science.287.5459.1770.

Smith JJ. 1993. Using Anthropac 3.5 and a spreadsheet to compute a freelist salience index. Cult Anthr Methods 9: 8-12. DOI: 10.1177/1525822X9300500301

Soberón J, Jiménez R, Golubov J, Koleff P. 2007. Assessing completeness of biodiversity databases at different spatial scales. Ecography 30: 152-160. DOI: $10.1111 / j .2006 .0906-7590.04627 . x$.

Sperens U. 1997. Long-term variation in, and effects of fertilizer addition on, flower, fruit and seed production in the tree Sorbus aucuparia (Rosaceae). Ecography 20: 521-534. DOI: 10.1111/j.16000587.1997.tb00421.x.

ter Braak CJF. 1987. The analysis of vegetation-environment relationships by canonical correspondence analysis. Vegetatio 69: 69-77. DOI: 10.1007/BF00038688.

Venables WN, Ripley BD. 2002. Modern Applied Statistics with S. $4^{\text {th }}$ ed. Springer, New York.

Verma RK, Kapoor KS, Subramani SP, Rawat RS. 2004. Evaluation of plant diversity and soil quality under plantation raised in surfacemined areas. Indian J For. 27:227-233.

Wallenius TH. 1999. Yield variations of some common wild berries in Finland in 1956-1996. Ann Bot Fenn 36: 299-314

Wang XP, Fang JY. 2012. Constraining null models with environmental gradients: a new method for evaluating the effects of environmental factors and geometric constraints on geographic diversity patterns. Ecography 35:1147-1159. DOI: 10.1111/j.1600-0587.2021.07384.x.

Wang, XP, Tang ZY, Fang, JY. 2006. Climatic control on forests and tree species distribution in the forest region of Northeast China. J Integr Plant Biol 48: 778-789. DOI: 10.1111/j.1744-7909.2006.00294.x.

Wang G, Zhou G, Yang L, Li Z. 2002. Distribution, species diversity and life-form spectra of plant communities along an altitudinal gradient in the northern slopes of Qilianshan Mountains, Gansu, China. Plant Ecol 165: 169-181. DOI: 10.1023/A:1022236115186.

Williamson M, Gaston K.J, Lonsdale WM. 2002. An asymptote is an asymptote and not found in species-area relationships. J Biogeogr 29: 1713-1713. DOI: 10.1046/j.1365-2699.2002.0079.x.

Whittaker RJ, Field R. 2000. Tree species richness modelling: an approach of global applicability? Oikos 89: 399-402. DOI: 10.1034/j.1600-0706.2000.890222.x.

Zhang CY, Zhao XH, von Gadow K. 2010. Partitioning temperate plant community structure at different scales. Acta Oecol. 36: 306-313. DOI: $10.1016 /$ j.actao.2010.02.003.

Zhuang L. Tian Z, Chen Y, Li W, Li J, Lu S. 2012. Community characteristics of wild fruit forests along elevation gradients and the relationships between the wild fruit forests and environments in the Keguqin Mountain region of Iii. J. Mt Sci 9: 115-126. DOI: 10.1007/s11629-012-2009-2. 
Zuazo, VHB, Pleguezuelo CRR, Flanagan D, Tejero IG, Fernández JLM 2011. Sustainable land use and agricultural soil. In: Lichtfouse E (eds). Alternative Farming Systems, Biotechnology, Drought Stress and Ecological Fertilisation. Sustainable Agriculture Reviews 6 . Springer, Dordrecht. DOI 10.1007/978-94-007-0186-1_5. 